Historic, Archive Document

Do not assume content reflects current scientific knowledge, policies, or practices. 

A MOUNTAIN VACATION LAND

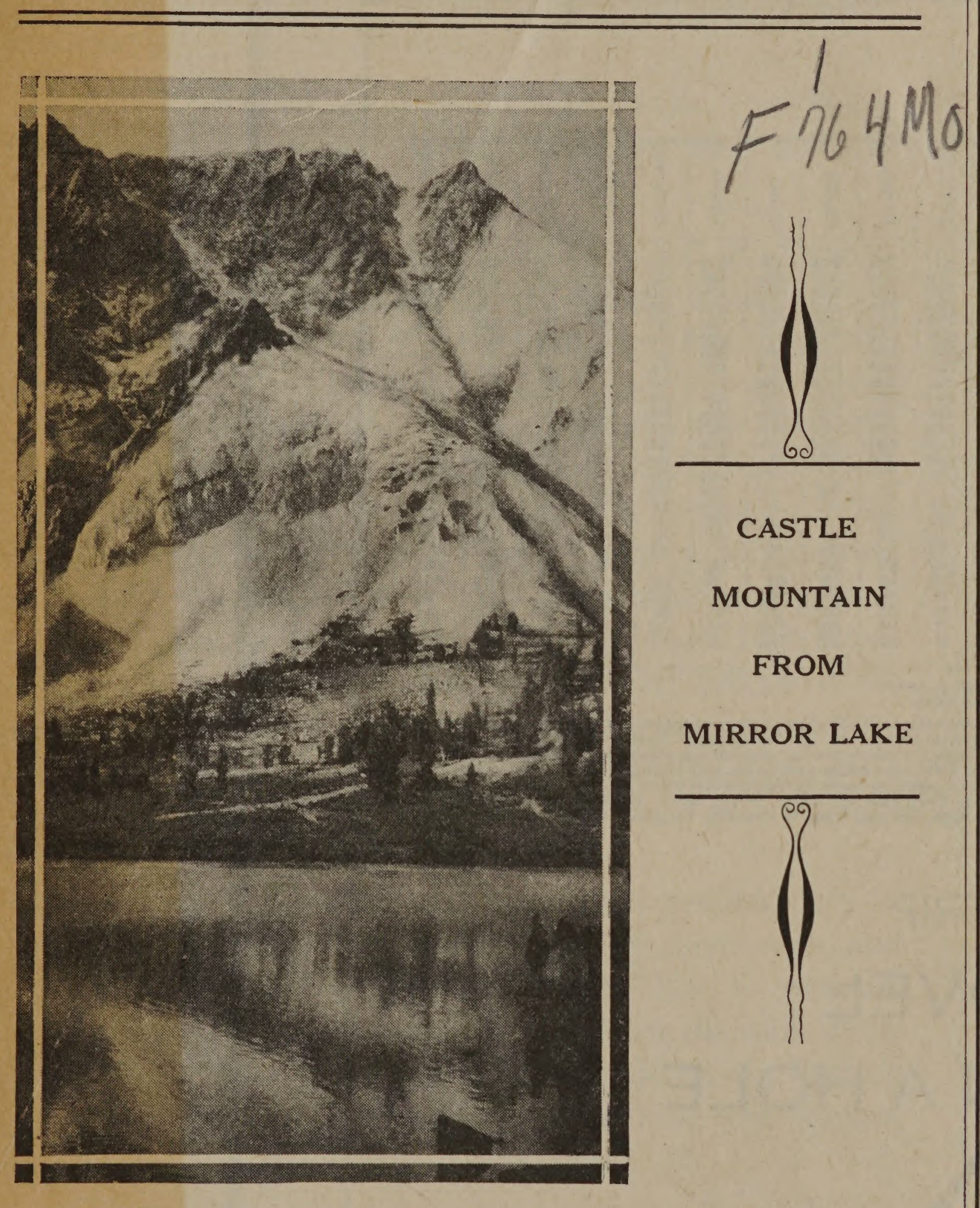

\section{THE NATIONAL FORESTS OF SOUTH CENTRAL IDAHO}





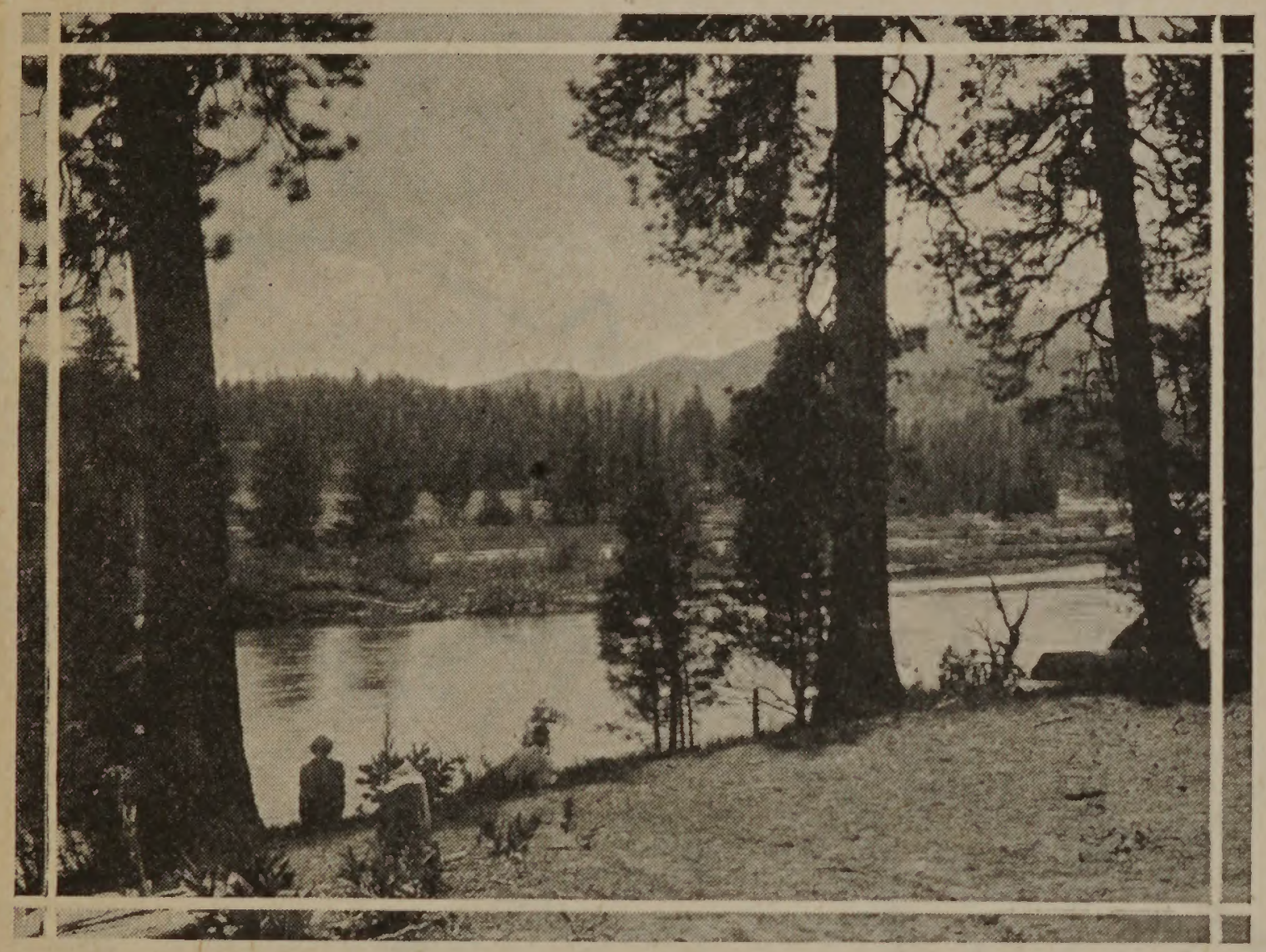

\section{ALONG THE NORTH FORK OF PAYETTE RIVER}

Payette Lakes, one of the most beautiful summer resorts in the West, can be reached from Boise or Emmett by auto in seven hours via Horseshoe Bend and Banks, Smith's Ferry, and Cascade. This is a wonderfully scenic trip. To those who love the rugged in nature, the trip through the North Fork Canyon with the steep timber-covered slopes, interposed with gray cliffs on the one hand and the rushing river broken by islands and cascades on the other, is a constant delight, while to others that part of the route through the green, level fields of Long Valley bordered by white-capped mountains with pine-clad slopes, is the most enjoyable. 


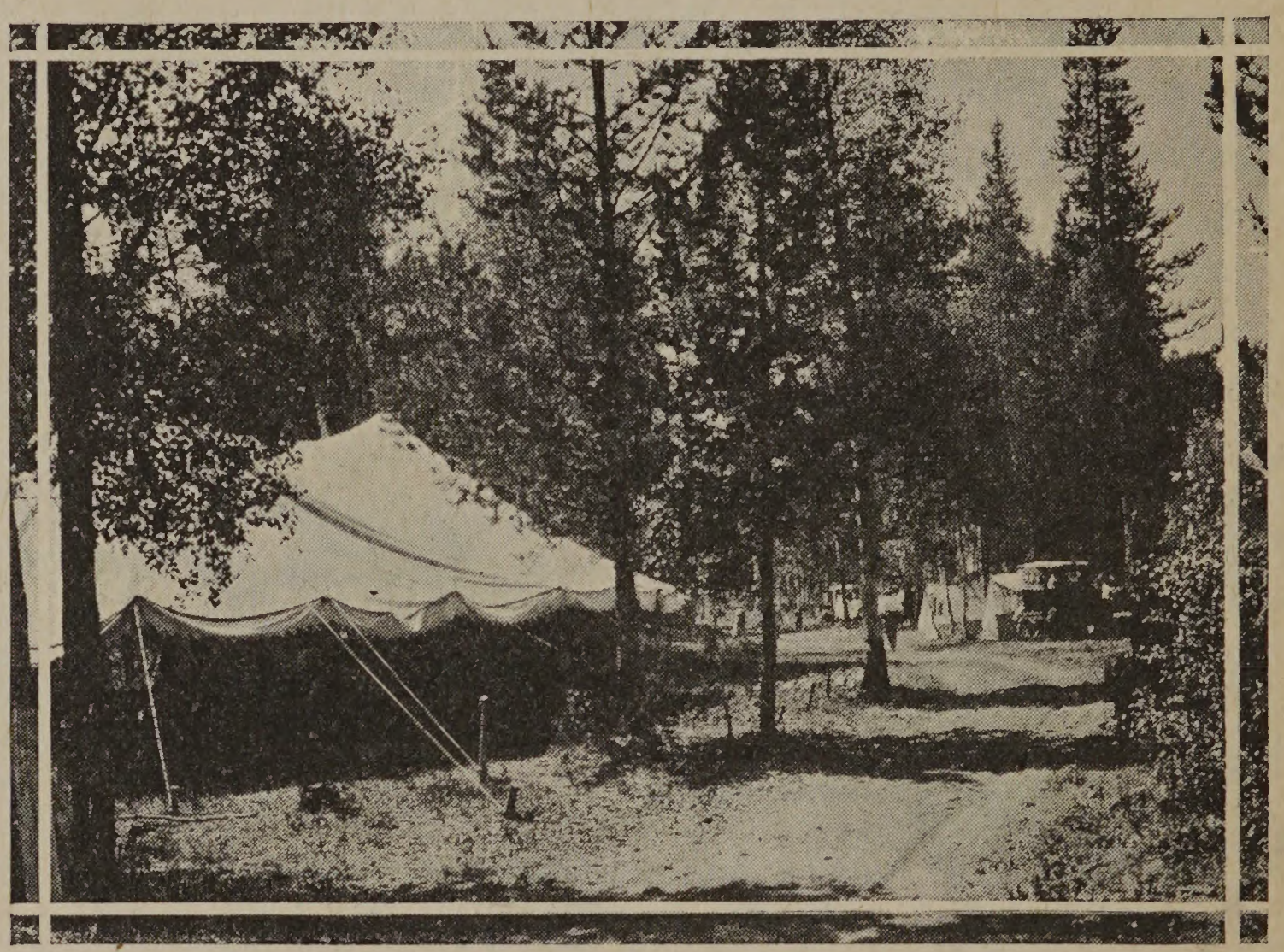

CAMP AT EASLEY HOT SPRINGS

At this point on the Hailey-Stanley Highway, 26 miles from Hailey, a public camp ground has been developed and improved by the Forest Service and cooperators. The camp is beautifully located, and a natural hot-water plunge, camp tables, fireplaces, and sanitary conveniences help to add to the comfort of the travelers who elect to stop here. Several thousand campers make use of the facilities at Camp Easley each summer. 


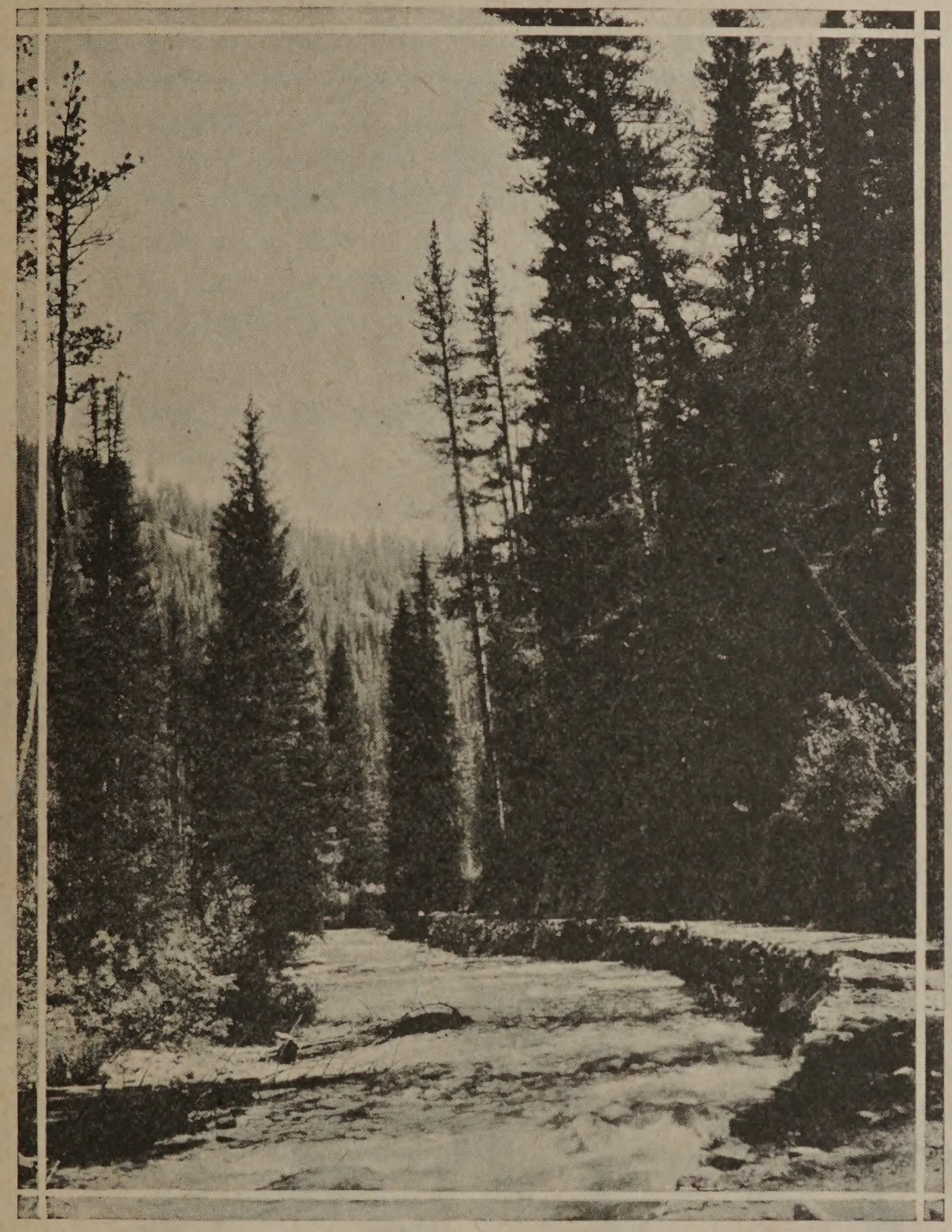

AN INVITING STRETCH OF FOREST ROAD

This beautiful scene along the Clear Creek Road in the Boise National Forest is typical of the natural beauty of many regions being steadily opened up through the construction of Forest roads. It is such scenes as this which afford unending delight to Forest visitors and which the Forest Service seeks your aid in preserving from devastation by fire. 


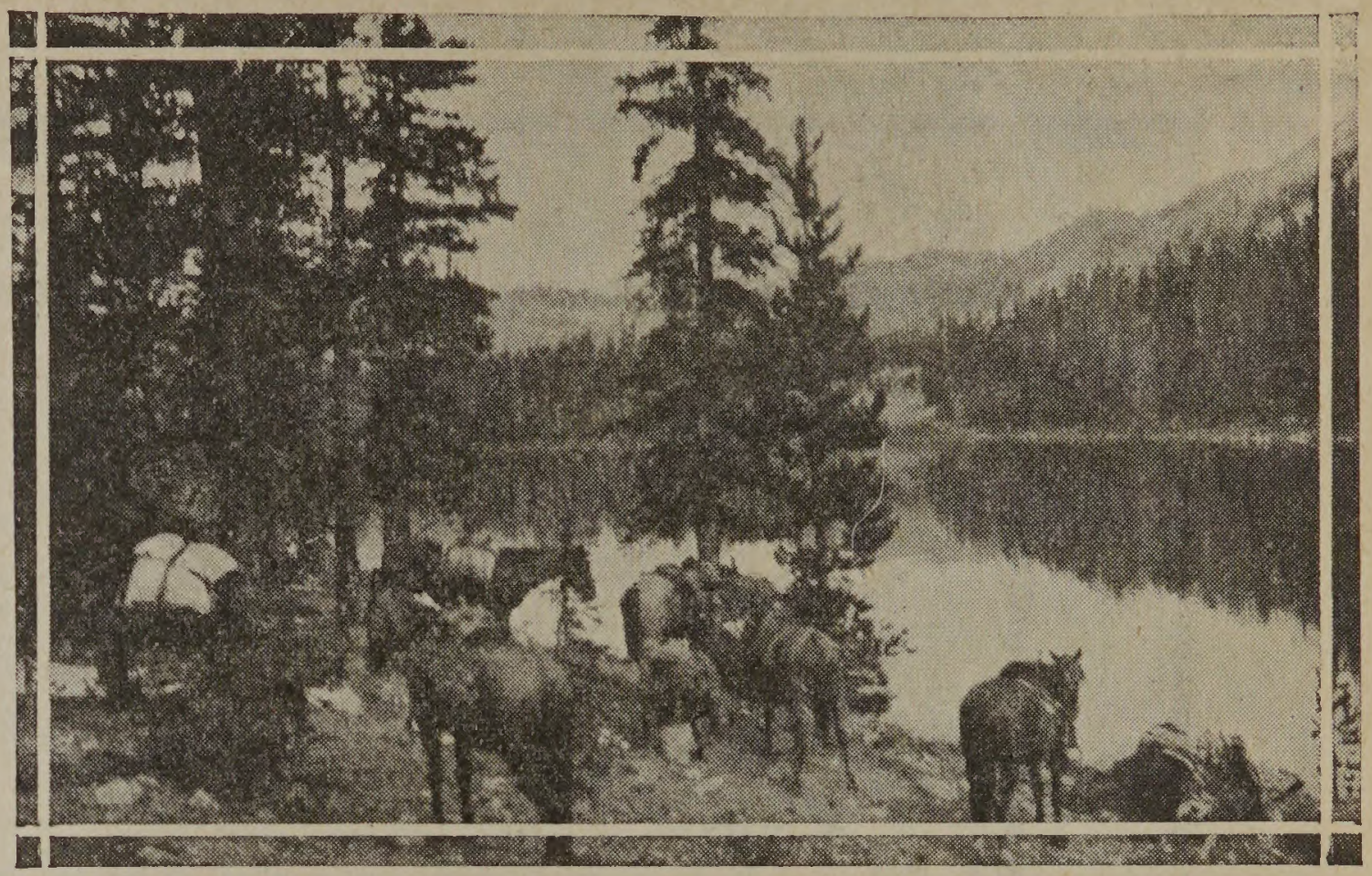

\section{BREAKING CAMP}

An early morning scene after a pleasant over-night camp in the Forest

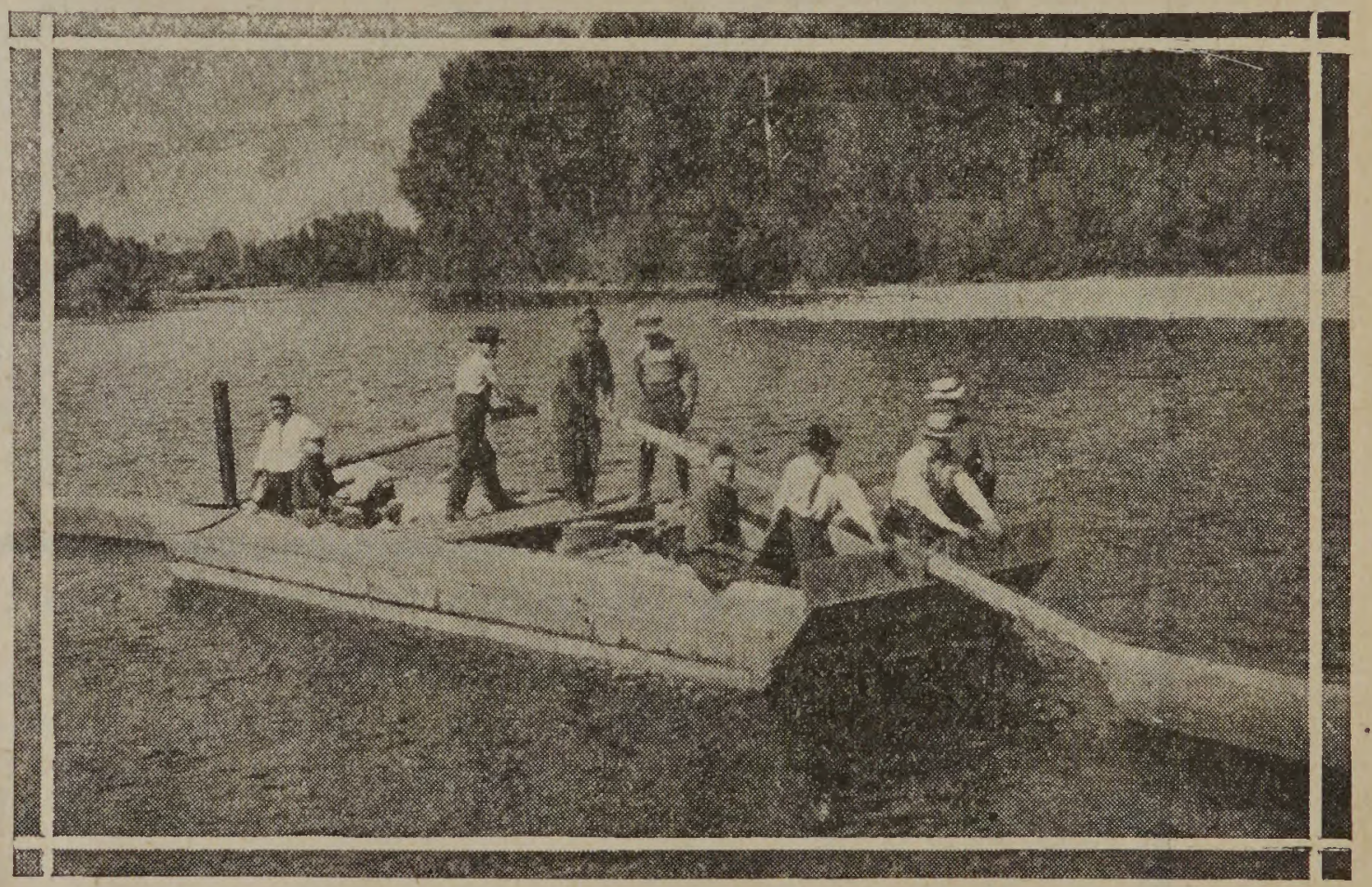

\section{ALL ABOARD FOR LEWISTON}

The 300-mile trip by river from Salmon City to Lewiston, Idaho, is made only under the guidance of Captain Gueleke in his personally designed river craft. The boats are made at Salmon City and on reaching Lewiston are wrecked and sold for lumber. The return trip must be made overland, since it is impossible to navigate against the rushing current of the Salmon. The scenic beauty of Salmon River is unexcelled and the exciting and exhilarating sport of shooting the numerous rapids furnishes a neverto-be-forgotten experience. The journey requires a week or ten days, depending upon the amount of time the party devotes to exploration of the beautiful side canyons, fishing, camping, or hunting. 


\section{THE NATIONAL FOREsts}

\section{OF \\ SOUTH CENTRAL IDAHO}

The eight National Forests shown on this map and treated in the following pages embrace a mountainous region of slightly more than ten million acres, bounded on the north by the main Salmon River and extending south and west to the Snake River Valley and east to the Montana line.

\section{A PRICELESS HERITAGE}

Primarily, the Forests constitute a vast region of tremendously valuable natural resources-a priceless heritage of timber, range, and watersheds, vitally essential to the future economic and civic welfare of southern Idaho and, indirectly, of the Nation as a whole.

\section{TIMBER}

It is estimated that these Forests contain 25 billion board feet of merchantable timber-a huge reservoir of building material, which, with the nearing exhaustion of other more accessible sources of supply, must be increasingly drawn upon to supply the timber needs of both local and distant markets. The principal timber species of the region are Douglas fir, western yellow pine, Engelmann spruce, and lodgepole pine, and, in addition, there is a considerable quantity of aspen and other cordwood species. These eight Forests hold one-fifth of Idaho's total timber stand, and the value of their merchantable timber is conservatively placed at $\$ 50,000,000$.

\section{FORAGE}

At present the summer grazing of live stock is the leading use of this group of Forests. Annually their protected range areas provide summer pasturage for 900,000 head of sheep and nearly 100,000 head of cattle and horses, in addition to 
the natural increase of these great herds. The stock grazing within these Forests are owned by over 1,600 stockmen and ranchers, local residents, and property owners of southern Idaho. It is thus obvious that the proper management and perpetuation of the Forest range resource is of major importance to the live stock industry, one of the basic industries of the commercial and civic development of the State.

\section{IRRIGATION}

The water flowing steadily from these protected Forest watersheds may truly be termed the "lifeblood " of irrigated agriculture in southern Idaho. The great Minidoka, Twin Falls, and Boise-Payette projects are altogether dependent upon the water derived from the winter snow stored in the distant mountains. Without it the production of agricultural crops would be impossible. Without the maintenance of normal conditions of forest cover, erosion and floods would occur, as has been the case in innumerable instances where the vegetable cover has been removed by fire, overgrazing, or other causes, and the great reservoirs now storing water for irrigation would be filled with silt and débris. This very thing has happened, not only in far away China, where to-day there is untold suffering and want directly traceable to the reckless destruction of the mountain forests in centuries past, but in some of Idaho's closely neighboring States.

\section{DOMESTIC WATER SUPPLY}

Scores of southern Idaho cities and towns derive their domestic water supplies from the crystal springs and streams rising in the mountain Forests. The purity and regularity of their flow is thus a matter closely related to the daily welfare of the average citizen.

\section{WATER POWER}

The mountain streams, with their rapid fall and generous flow, constitute a water-power resource of almost unlimited future value, and with the impetus afforded by encouraging legislation will be steadily harnessed in greater measure to furnish light, heat, and industrial power. 


\section{RECREATION}

Great as are these "practical" values and possibilities of the central Idaho group of National Forests, it is as a recreation area-a vast public summer playgound-that the region is rapidly becoming most widely and favorably known. As the roads, trails, telephone lines, and other improvements (constructed by the Forest Service and cooperative agencies primarily for protective and administrative purposes) have opened up to travel the hitherto inaccessible regions, increasing thousands of summer visitors are coming to the National Forests each year. They come from the cities, towns, and ranches of the southern Idaho valleys, and in greater numbers every summer from all sections of the country-near and far, south, east, and west.

The primary purpose in the administration of the Forests is to protect the timber and watersheds. All available funds are needed for this purpose, and we can not undertake to develop intensive use of the Forests for recreation. Such use may intensify the problems of fire protection, depending on the personal attitude of the recreationist. On the other hand, it is the policy of the Forest Service to make the great areas under its care of the greatest possible value and use to the public. It, therefore, cordially welcomes the recreationist, places at his service the facilities which the Forest organizations afford, and as rapidly as funds and available manpower will permit is so developing the recreational features of the Forests as to make the stay of the visitor thoroughly pleasant.

For those who come there is no disappointment. Health is here in the invigorating air and sunshine, away from the heat, the dust, the smoke, and the nerve-destroying noise and rush of the cities. The joys of the open road call on every side. Scenic beauty and grandeur delight the eye and feast the soul. Camp life in the shelter of the mighty forest's and the pleasures of the rod and gun tempt the sportsman, the weary business man, and their families as well. The giant peaks, rugged canyons, beautiful mountain lakes and streams, unusual geologic formations, and unexplored sections call with compelling voice the mountain climber, the scientist, the artist, and all lovers of the great outdoors. 


\section{HELP PERPETUATE THESE RESOURCES BE CAREFUL WITH FIRE IN THE MOUNTAINS}

\section{FREEDOM OF ACTION}

No burdensome restrictions upon recreational use are imposed. Public camp grounds are being developed at convenient points, summer home sites may be leased for exclusive use at low rates, or the vacation seeker is free to camp and travel where his fancy leads him. In extending a cordial invitation to the public to summer in the National Forests, the Forest Officers expect in return only the active, whole-hearted cooperation of the public in preventing forest fires, in the suppression or reporting of any fires discovered, and in the observance of the sanitary requirements essential to maintaining the purity of the forest streams and the cleanliness of the forest camps.

Detailed maps and more complete information regarding the individual Forests of the central Idaho group and details of particularly enjoyable trips may be obtained from the Forest Supervisors at Boise, Emmett, Weiser, McCall, Challis, Salmon, Mackay, or Hailey, Idaho. Information concerning this region may also be obtained from the Oregon Short Line Railroad, at Boise, Idaho, and H. W. L. Niemeyer, Secretary, Idaho State Automobile Association, Nampa, Idaho.

In visiting the Forests, get and keep in touch with the Supervisors and Rangers. They can very often render valuable assistance to visitors and are always glad to do whatever they can.

In the following pages the general recreational attractions of this group of National Forests are discussed under two subdivisions, eastern and western groups, into which the region as a whole is naturally divisible. This makes for a more ready understanding by the reader of the general layout of the country and its connections with the through routes of travel.

\section{Leave a Dead Fire and a Clean Camp}




\section{WESTERN GROUP}

IDAHO, PAYETTE, WEISER, AND BOISE NATIONAL FORESTS

\section{TRAVEL ROUTES}

In general, this section is accessible from the Oregon Trail in Idaho west of Boise and the North and South Highway between Boise and the Salmon River. The principal towns on the routes of entrance are Boise, Nampa, Caldwell, Emmett, Payette, Weiser, Council, Idaho City, Cascade, New Meadows, and McCall. Rail connections over the Oregon Short Line are had from Weiser to Council and New Meadows and from Nampa via Emmett, Banks, and Cascade to McCall. For stage connections see map.

\section{SEVEN DEVILS MOUNTAINS (Weiser National Forest)}

Accessible by auto road to Bear or Landore from Council or Ballards Ferry. From Landore by wagon or saddle outfits.

There is here an intermingling of rugged granite peaks with crystal streams or lakes and mountain meadows. Bird hunting, fishing, and camping are available. There are several other areas farther south, such as Lost Valley Reservoir, Cuddy Mountains, and Hitt Mountains, of interest to recreation seekers.

\section{PAYETTE LAKES SECTION (Idaho National Forest)}

Reached by auto from North and South Highway and from train at New Meadows or McCall.

There is excellent camping, boating, bathing, and good trout fishing at times at the Payette Lakes, where camp and hotel accommodations are available. Auto trips can be made to headwater streams, or by horse outfits into the mountains, to excellent fishing, hunting, camping, or huckleberry grounds. This section is easily accessible, is the most popular as a tourist center of any within this group, and has many attractive features. The trip from Boise or Emmet via Banks and Cascade through the canyon of the North Fork of the Payette River is particularly scenic. 
UPPER SOUTH FORK OF SALMON RIVER (Idaho and Payette National Forests)

Reached by auto or stage from Cascade to Knox, or by horse outfit from McCall or Lake Fork (inlet to Little Payette Lake). Horse outfits to mountains from Knox. Trails connecting to other points shown on map. This is a rough, rugged country not extensively visited by tourists, but which provides excellent camping, trout and salmon in great abundance, and fine deer, bear, and bird hunting in season. Hotel accommodations at the beautiful Warm Lake near Knox.

\section{LOWER SOUTH FORK SALMON RIVER}

Accessible by auto or stage over a fair road from McCall to Burgdorf, Warren, and South Fork. A trip into this section takes the tourist to very best fishing and hunting available to this means of transportation. An excellent hot springs and hotel are at Burgdorf, and there is a hotel at Warren.

\section{MIDDLE FORK SALMON RIVER-LOWER SECTION (Idaho National Forest)}

Accessible by saddle outfits from Warren and Edwardsburg or Knox via Roosevelt.

The immense drainages of Chamberlain and Big Creeks include the wildest, most undeveloped section of central Idaho. There is excellent fishing everywhere and an abundance of deer, bear, and mountain goats. Excellent elk hunting in Chamberlain Basin. For the person who can undertake an extensive pack trip, this region offers the greatest opportunity for fishing, big-game hunting, or wild life study. Persons unfamiliar with the country should employ guides.

\section{MIDDLE FORK SALMON RIVER-UPPER SECTION (Idaho and Payette National Forests)}

Accessible from Emmett or Boise through Knox or Lowman. Fair automobile road into Bear Valley from Lowman or from Stanley (Eastern Group). Remainder of area accessible to pack outfits. 
Sulphur and Pistol Creeks as well as the main river offer excellent deer and mountain goat hunting and fishing for trout and salmon. Bear Valley is well known for its trout fishing and sea salmon in early fall. There are many interesting side trips from the main lines of travel.

\section{SOUTH FORK OF PAYETTE RIVER (Payette and Boise National Forests)}

Accessible by auto or stage through Banks, Placerville, and Pioneerville to main streams and foot or pack outfit to other points.

There is a fair abundance of deer, bear, and small game, and excellent fishing. Attractive camp grounds, hot springs, mountain climbing, and scenic features are abundant. The upper section above Lowman is particularly well supplied with hot springs. It heads against the Sawtooth Peaks in a region of exceptionally beautiful mountain peaks with numerous small lakes. Most of this area is included within a State Game Preserve and provides an excellent opportunity for the study of wild game, particularly deer, elk, and mountain goats. Trips may be made from Lowman to the head of the Middle Fork of the Salmon River and to Stanley and the Redfish Lake Country or across to the North or Middle Fork of the Boise River.

\section{BOISE RIVER (Boise National Forest)}

The various branches of this river are accessible only in part by auto or stage lines from Idaho City, Arrowrock, and Twin Springs, and via Pine and Rocky Bar to Atlanta. There are excellent connecting trails allowing desirable circle trips. From Atlanta one can cross by trail to the Redfish Lakes. A trip to the Forest may include the famous Arrowrock Dam, the highest in the world.

Although much broken, this section is very rugged only where the Middle Fork heads against the Sawtooth Peaks. There is excellent fishing and good deer and bird hunting. The scenery, particularly along the streams, is delightful, and there are many attractive camp spots. Guides are generally available at Idaho City and Atlanta. 


\section{EASTERN GROUP}

\section{SAWTOOTH, CHALLIS, LEMHI, AND SALMON NATIONAL FORESTS}

\section{TRAVEL ROUTES}

Access is had to this section over auto roads from Boise, Twin Falls, Mountain Home, Gooding, Shoshone, and Hailey from the southwest. Roads from the southeast lead from Pocatello, Blackfoot, Idaho Falls, and Dubois. Also roads from Dillon, ,Montana, via Redrock, Montana, and from Missoula, Montana, via Big Hole Basin. Railroad connections over the Oregon Short Line to Hailey, Mackay, and Salmon City with stage lines shown on map.

Very desirable auto trips over good roads with easy grades may include Wood River, Sawtooth Lakes, Salmon River, or Lemhi Valley, making a circuit or connecting with through trips. The map shows the connecting routes between the different sections.

Trips through this section fit well with travel east and west or north and south through Idaho, or from the south and west to the Yellowstone or Glacier National Parks.

SOUTH BOISE RIVER (Boise and Sawtooth National Forests)

Accessible by auto from Boise, Mountain Home, and Hailey, and by auto stage from Mountain Home to Atlanta. It is closely connected with the Boise River section of the western group. The upper stream is reached over fair auto road from Soldier.

The attractions here are numerous hot springs and excellent camping and fishing along the South Boise River and good bird hunting and fair deer hunting in season.

Hotels at Pine, Featherville, and Rocky Bar. Camp grounds and main streams are reached by auto, other points by saddle or foot.

\section{WOOD RIVER (Sawtooth National Forest)}

Reached through Hailey from southern Idaho, from Mackay over Trail Creek Summit (steep grade), or from Sawtooth Lakes section. Rail connection on Oregon Short Line at Hailey. 
Wood River is an excellent trout stream, although very accessible and heavily fished. Several large forks, as well as the main stream, offer excellent fishing. Camp grounds furnished with conveniences for the traveler at frequent distances. Hot springs of high quality are numerous. Side trips by pack outfits or foot to the rugged mountain section in which is Mount Hyndman (12,078 feet), the highest peak ir Idaho. Desirable summer home locations available. Fair bird hunting away from main roads.

Excellent hotel and hot springs resorts at Hailey, Deer Creek, and Ketchum add to the comfort of travelers or provide permanent accommodations.

\section{SAWTOOTH MOUNTAINS-REDFISH LAKES (Sawtooth and Challis National Forests)}

Accessible by good auto road from Hailey, Mackay, Challis, and Salmon. Rail connections at Hailey and rail and stage from Mackay and Salmon.

The Sawtooth region is deservedly popular as a recreation ground and offers a variety of attractions. Rugged mountain peaks, clear streams, and green forests with numerous alpine lakes offer a choice of many forms of recreation. The main automobile roads lead through delightful country where hot springs, good fishing, and bird hunting or plain restful camping are available. The Redfish Lakes, nestled in the timber at the base of the rugged Sawtooth Peaks and of easy access by auto, attract many tourists. Trout fishing is not yet good at the lakes, but they are being stocked. Excellent fishing can be had in the streams and some of the smaller lakes. Little redfish, a small fresh water form of the Pacific sockeye salmon, spawn in the lake inlets in August and are taken in numbers. Pack trips may be made to the Boise River, Payette River, East Fork, Castle Peak, and White Cloud Peaks sections, where there is excellent fishing and wonderful scenery; or trips on foot may be taken to the glacial basins in the Sawtooth Peaks.

There is a hotel at Stanley, and accommodations may be had at various ranches. Excellent camping spots are available. Guides are obtainable in the Sawtooth Valley and Stanley Basin. 
MIDDLE FORK SALMON RIVER (Challis and Salmon National

Forests)

Accessible by auto from Stanley to the vicinity of the Loon Creek Ranger Station. From either there, Bonanza, or Challis by pack outfit. The lower part of this region may be reached from Salmon City by stage, wagon, or pack to Forney and Meyers Cove.

This is a wild, undeveloped country furnishing the very best of deer and bear hunting and trout and salmon fishing. Mountain goat and mountain sheep are not uncommon, but are protected from hunting. It is particularly attractive to the big game hunter and fisherman as well as the camper who likes to visit wild, little-frequented country. There are numerous hot springs and desirable camping spots. Accurate maps are not yet available and guides, obtainable at Stanley, Challis, or Salmon, would be necessary for persons unfamiliar with this section. It is possible to go from here into the Middle Fork units described in the Western Group. The trails are good and travel not difficult.

\section{SALMON RIVER FROM STANLEY TO CHALLIS (Challis National Forest)}

Accessible from auto road connecting Stanley, Mackay, and Challis. Auto roads up Yankee Fork and East Fork, foot or horse trips to other points.

Several attractive camping places are near the highway, and the fishing is good in the river and streams. Accommodations may be had at several hotels, and there is an attractive resort with hot springs pool at Robinson Bar. The East Fork country, the White Cloud Peaks, and the head of Yankee Fork offer excellent side trips into very attractive country where fishing and hunting are assured. Below the Sunbeam Dam fishing is allowed year long and is particularly good in early spring.

\section{LOST RIVERS (Lemhi National Forest)}

Entrance to this country may be made from Hailey and Blackfoot through Arco or Idaho Falls, Dubois, Salmon, Challis, and Stanley. Even from these points there is a choice of several routes. Rail connections are had to Mackay, and auto stage from Challis and Salmon City. 
The features of particular attractiveness are the fishing in Big Lost River above Mackay, large rainbow and eastern brook trout being very abundant; the excellent sage hen hunting in practically all the valleys; trips through wonderful scenery on Wildhorse Creek to Mount Hyndman, the highest peak in Idaho; the interesting trip through Pass Creek Canyon; deer hunting in the mountains east of the Pahsimroi and the opportunity. to observe antelope, mountain sheep, and mountain goats. Trips into this section may well be extended to the Salmon River and Sawtooth sections. An excellent road system, stage lines, direct rail connections, and numerous hotels or outfitting points furnish accommodations for all classes of tourists.

\section{SALMON RIVER AND LEMHI RIVER (Challis and Salmon National Forests)}

Access is had by auto along main roads from Big Hole Basin and Red Rock in Montana and from Dubois, Idaho Falls, Mackay, and Challis in Idaho. Train service to Salmon; stages shown on map.

Along the main roads there are excellent camping grounds, good trout and salmon fishing and bird hunting. The scenery along the beautiful Salmon River is very attractive. Short side trips to interesting areas are possible. From Shoup (reached by auto), Salmon, or points along the Salmon-Meyers Cove stage line, pack trips may be made to Big Creek, Yellow Jacket, Horse, and Owl Creeks or to Middle Fork of Salmon River points. This is a wild, undeveloped section offering excellent trout and salmon fishing and bear and deer hunting as well as the opportunity to see mountain sheep and mountain goats. Although in very rough country, the trails are good, and it is possible to obtain supplies at various ranches.

A wonderful trip is possible with Captain Gueleke in flat boats from Salmon through the canyon of the Salmon River to Lewiston. Such a trip furnishes plenty of thrills and is not without risk. It takes one through wonderful fish, game, and scenic country, not accessible otherwise.

\section{There is More Honor in Preventing a Forest Fire Than in Putting It Out}




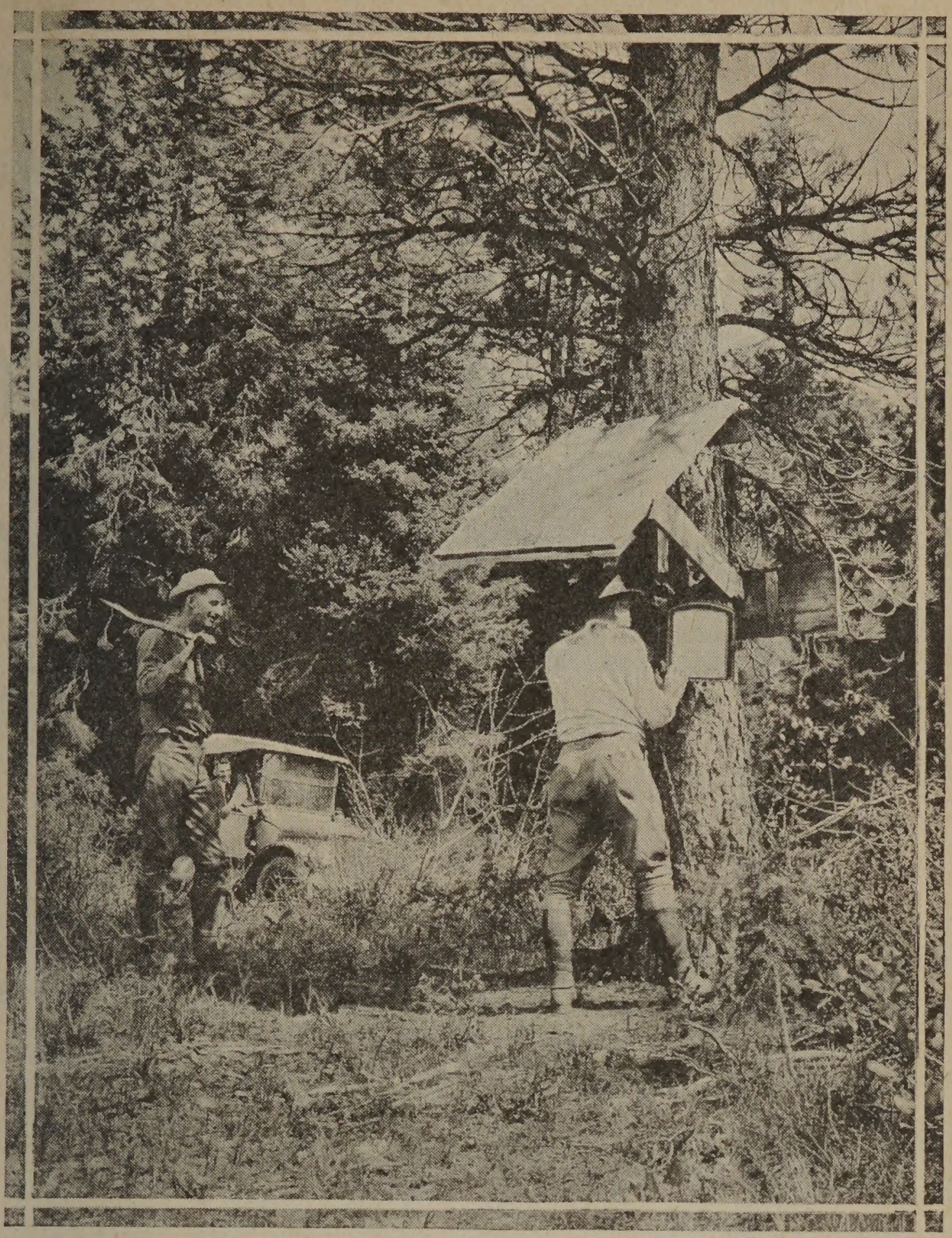

\section{SIX RULES}

For Care With Fire in the Mountains

1. Be sure your match is out. Break it in two before you throw it away.

2. Throw pipe ashes and cigar or cigarette stubs in the dust of the road and stamp or pinch out the fire before leaving them. Don't throw them into brush, leaves, or needles.

3. Build a small camp fire. Build it in the open, not against a tree or log or near brush. Scrape away the litter all around it.

4. Never leave a campfire, even for a short time, without quenching it with water and earth.

5. Never build bonfires in windy weather or where there is the slightest danger of their escaping.

6. If you find a fire try to put it out. If you can't, get word to the nearest forest ranger or State fire warden at once.

\section{Keep in Touch With the Rangers}




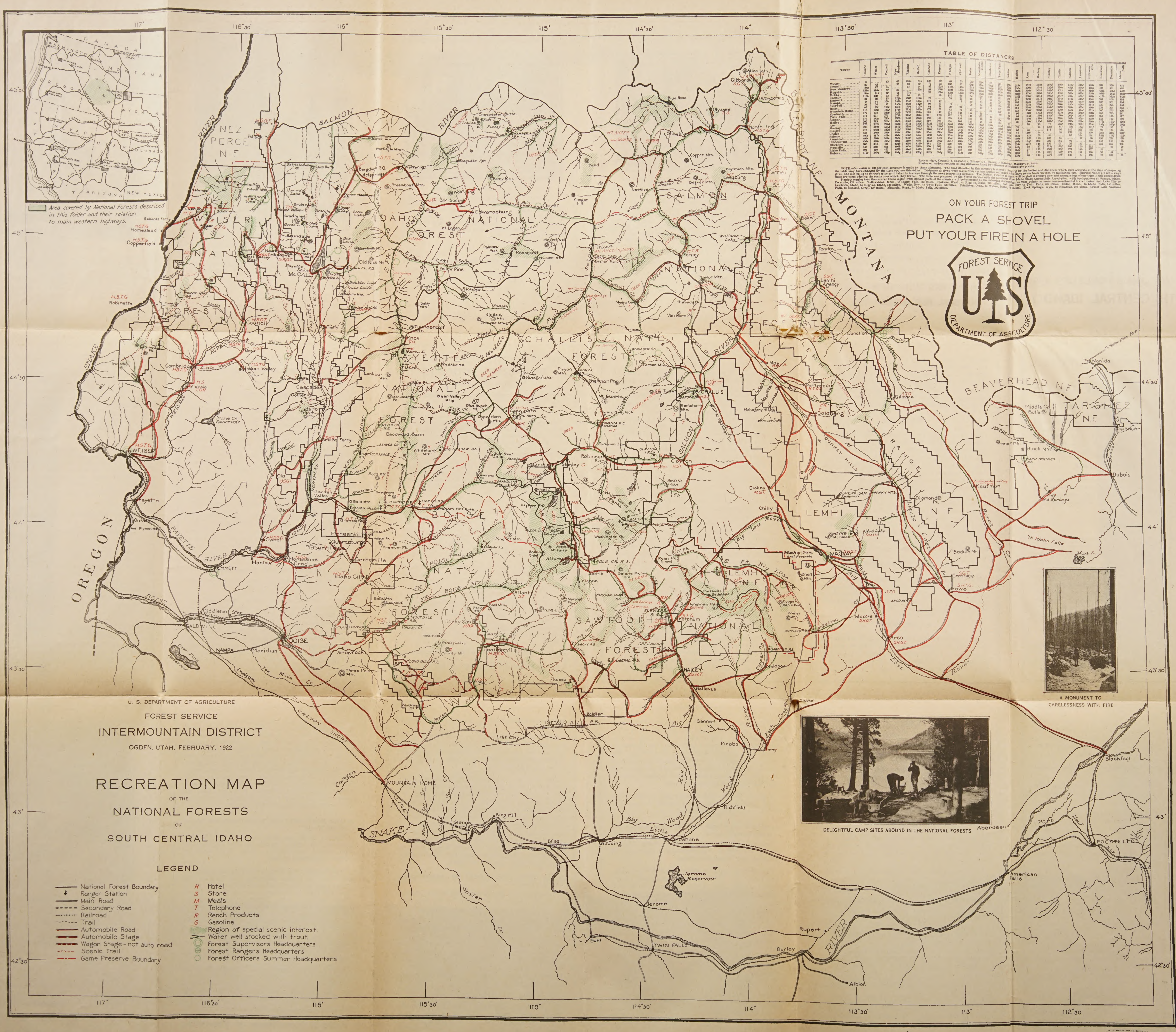


THE NATIONAL FOREST OF

SOUTH CENTRAL IDAHC

SAWTOOTH

CHALLIS

SALMON

BOISE
LEMHI

PAYETTE

WEISER

IDAHO

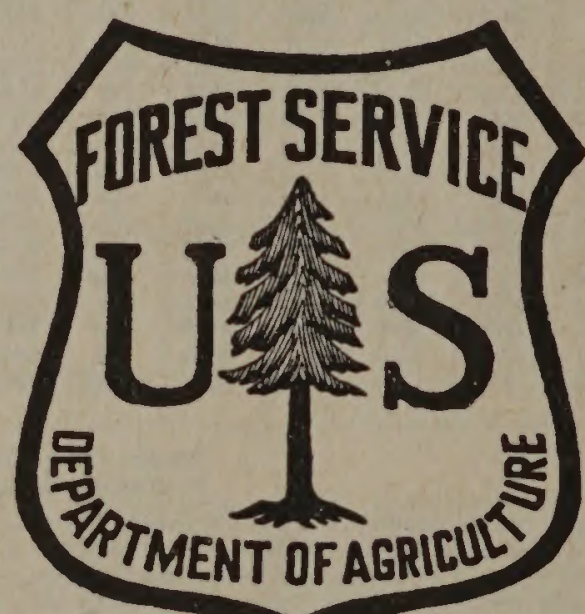

Timber - Water Power - Minerals

Forage - Scenic Grandeur

Fishing - Camping - Hunting

USE AND ENJOY THE FORESTS

HELP PROTECT THEIR GREAT

NATURAL RESOURCES 